\author{
Dr Irena Grugulis \\ Manchester School of Management \\ UMIST \\ PO Box 88 \\ 'Manchester \\ M60 1QD
}

Tel: 01612004168

Fax: 01612003505

Email: Irena.Grugulis@umist.ac.uk

and

Professor Adrian Wilkinson

Professor of Human Resource Management

Loughborough University Business School

Ashby Road

Loughborough

Leics

LE11 3TU

England

Tel: 01509228273

Fax: 01509 223960

Email: a.j.wilkinson@lboro.ac.uk 


\section{MANAGING CULTURE AT BRITISH AIRWAYS: HYPE, HOPE AND REALITY}

Irena Grugulis and Adrian Wilkinson

Long Range Planning, Forthcoming 2002 


\section{MANAGING CULTURE AT BRITISH AIRWAYS: HYPE, HOPE \\ AND REALITY}

\section{Executive Summary}

Nearly twenty years after the publication of the (in)famous In Search of Excellence, the notion of 'cultural change' within organisations continues to excite attention. This continuing attraction is readily understood, since cultural interventions offer practitioners the hope of a universal panacea to organisational ills and academics an explanatory framework that enjoys the virtues of being both partially true and gloriously simple. Such a combination is apparent in the way that many attempts to shape organisational culture are presented to the public: as simple stories with happy endings. ${ }^{1}$

Accordingly, in this article we attempt to rescue a fairy-tale. The story of British Airways is one of the most widely used inspirational accounts of changing culture. Throughout the 1980s and 1990s it was used to demonstrate the necessary compatibility of pleasure and profits. $^{2}$ In the celebratory accounts, culture change is presented as the only explanation for the transformation that occurred. This corrective makes no attempt to deny the very substantial changes that took place in BA. Rather, it sets these in context noting the organisation's environment at the time of the transformation, the structural changes that took place and observing the impact that such changes had over the long term. , $^{3,5}$ 


\section{MANAGING CULTURE AT BRITISH AIRWAYS: HYPE, HOPE AND REALITY}

Today, nearly twenty years after the publication of the (in)famous In Search of Excellence, the notion of 'cultural change' within organisations continues to excite attention. This continuing attraction is readily understood, since cultural interventions offer practitioners the hope of a universal panacea to organisational ills and academics an explanatory framework that enjoys the virtues of being both partially true and gloriously simple. Such a combination is apparent in the way that many attempts to shape organisational culture are presented to the public: as simple stories with happy endings. ${ }^{6,7}$

To a certain extent, of course, any form of narration encourages a story, an ending, and, as a result, a simplification and stories may be used to shed light on attitudes and understandings not otherwise easily available to the researcher. But there is a very significant difference between listening to the accounts that individuals tell in order to make sense of their lives and allowing the study of the workplace to become 'fictionalised'. The former involves engaging with the 'subjects' of the research, attempting to understand their world view and allowing them a voice in the process they are participating in. The latter can mean a selective reading of the data with examples chosen because they illustrate pre-set conclusions.

In management particularly the capacity of writers to turn case studies into celebratory fictions is worrying. As Marchington ${ }^{8}$ argues, too many texts focus on "fairy tales and magic wands". Such an emphasis encourages the belief that what is important in the workplace is not context, structure, power, economics or industrial 
relations but whatever new initiative management have chosen to introduce (the "magic wands"). The form that this magic takes varies from intervention to intervention but the impact claimed for each is curiously similar with unproductive workplaces turned around and reluctant employees transformed into enthusiasts. Any changes that take place are seen to be a direct result of the magic and most are exaggerated. As a result, research into management becomes research into a series of fads and fashions with Total Quality Management or Business Process Reengineering or empowerment or culture vying for attention and every intervention presented as new. So academic understanding of the workplace starts afresh each time a guru develops a new magic wand. Lessons cannot be carried forward since BPR is not employee involvement and company culture is not TQM. Elements of the workplace that might have provided a crucial element of continuity are ignored or dismissed as unimportant since only change is magical. As a result, by relying on these accounts, we understand less and less about why organisations function in the way that they do and practitioners are encouraged to believe that each initiative starts with a blank sheet, entirely unconstrained by what has gone before.

Accordingly, in this article we attempt to rescue a fairy-tale. The story of British Airways is one of the most widely used inspirational accounts of changing culture. Throughout the $1980 \mathrm{~s}$ and $1990 \mathrm{~s}$ it was used to demonstrate the necessary compatibility of pleasure and profits; ${ }^{9}$ In the celebratory accounts, culture change is presented as the only explanation for the transformation that occurred. This corrective makes no attempt to deny the very substantial changes that took place in BA. Rather, it sets these in context noting the organisation's environment at the time of the 
transformation, the structural changes that took place and observing the impact that such changes had over the long term. ${ }^{10,11}$

Managing Culture: Promises and Problems

In many respects, managing culture is peculiarly susceptible to being presented as a corporate fiction. While other management initiatives seek to promote positive attitudes by increasing employees' area of responsibility through empowerment aligning their financial interests with those of the organisation through adjustments to the payment system or demonstrating an organisational commitment to its 'human assets' by investing in training, cultural change targets employee attitudes directly and aims to secure 'commitment' rather than 'resigned behavioural compliance' ${ }^{12}$ with all employees sharing a 'common vision' and working together for the good of the organisation.

As a result, the managerial task becomes one that involves establishing control over the meaning of work, rather than its execution, of 'converting' employees to the corporate 'faith'. In the words of Peters and Waterman ${ }^{13}$ managers' jobs become "more fun. Instead of brain games in the sterile ivory tower, it's shaping values and reinforcing through coaching and evangelism in the field - with the worker in support of the cherished product". When the managerial task is to inspire and enthuse, it follows that, if management academics are management's advocates and apologists their task is to provide prescriptions, exemplars and celebrations. Such accounts exist to provoke an emotional response and provide a spur to action and, to fulfil these functions, must necessarily describe productive interventions. In this narrative tradition management fads and fashions can only succeed. 
So, not only is culture as a topic particularly likely to be represented as fiction, but also management writers may see their role as essentially celebratory. For those who read case studies to be inspired and enthused this combination is probably welcome. Others, who seek to understand the way organisations function, assess the impact of interventions on employees, consider how structural and strategic factors combine, or even (through their writing) contribute towards a wider, emancipatory agenda; prefer accounts that do not automatically seek to report triumphs. In these, the management of culture is depicted as something rather more complex than a 'magic wand', 'successes' are more than counter-balanced by initiatives with mixed or negative results and interventions are not assumed to be permanent 'fixes'. ${ }^{14,15}$

Occasionally the failures of culture management programmes are comic, Collinson ${ }^{16}$ argues that many of the initiatives designed by one British factory's (new, American) management served only to inspire shop-floor humour including stigmatising the company newsletter as 'Goebel's Gazette'. Hamper's ${ }^{17}$ account of his time at General Motors included the story of the quality cat 'howie makem' whose job was to patrol the factory exhorting workers to produce higher quality. The General Motors' employees reacted to this by producing their own 'quantity cat' who (fittingly) chased 'howie makem' off the factory floor. And British employees of the Gap, a US-owned clothes chain, produced their own version of the organisation's mission statements (see Fig. 1):

FIGURE 1 ABOUT HERE 
Other accounts of cultural interventions are less amusing. Keenoy and Anthony ${ }^{18}$ note that shortly after the TSB launched its culture change programme (which aimed to construct an 'achievement orientated culture') it announced that some 5,000 staff were to be made redundant; and Ogbonna and Wilkinson's ${ }^{19,20}$ research into culture change in supermarkets describes practices that are very stressful for the checkout operators told to implement them. In many organisations, it seems, cultural interventions are simply a form of work intensification.

Significantly each of these references differs from the celebrations in their willingness to believe that culture's impact on employees is not automatically positive. This is not to argue that cultural interventions are never welcomed. Kunda $^{21}$ Casey $^{22}$ and Grugulis et al..$^{23}$ all describe environments in which enthusiastic staff welcomed the management of culture (though in both cases the impact of this was problematic). Watson's ${ }^{24}$ managers viewed ZCT's corporate culture changes with a mixture of hope and scepticism; and Storey ${ }^{25}$ notes that, while little sympathy was forthcoming from the shop floor, several line managers were supportive.

Going beyond the prescriptive accounts to understand organisations also raises questions on the efficacy of culture in securing 'bottom line' benefits. This coaching, evangelism and conversion, what Reed $^{26}$ describes as a shift from "control by repression to control by seduction" is done because it is assumed that employee commitment equates to higher profits. In part because employees will now invest their energy, enthusiasm and ideas without constraint; and in part this is because work is being re-defined in emotional rather than productive terms. ${ }^{27,28,29}$ In practice, of course, the link between a unitary culture and corporate profits is elusive. Indeed, not 
only is the failure of organisations actively engaged in culture management and high commitment work practices notable, but also anti-managerial cultures seem just as capable of fostering high levels of output as more consensual ones. ${ }^{30}$

Nor are fairy stories particularly helpful to managers. They may inspire and enthuse but, as the evidence shows, the product of this enthusiasm is rarely successful. Here, by exploring both success and failure realistically we hope to provide more achievable (of less ambitious) targets for 'managing culture'.

The British Airways Story

Even by the standards of modern management myths the British Airways transformation is impressive. At the end of the 1970s and the start of the 1980s BA was performing disastrously against almost every indicator. An old fleet made for uncomfortable journeys and contributed significantly to the airline's record for unpunctuality its productivity was considerably below that of its main overseas competitors it was beset by industrial disputes; and it was recording substantial financial losses ( $£ 140$ million or some $£ 200$ a minute in 1981 ). It seemed that staff discontent was more than matched by customer disatisfaction and in 1980 a survey by the International Airline Passengers' Association put BA at the top of a list of airlines to be avoided at all costs By 1996 this picture was reversed. Not only had BA become the world's most profitable carrier, it was also voted the company that most graduates would like to work for and, by the year 2000, another survey declared it the second most admired company in Europe. ${ }^{31,32,33,34,35}$ 
Much of the management literature attributes this turnaround to BA's own cultural change which remodelled staff attitudes and set customer care as the primary focus of activity. As Doyle ${ }^{36}$ noted:

In the $80 \mathrm{~s}$ BA had been transformed from a disastrous loss-making state enterprise - the British Rail of the sky - into the world's largest and most profitable international airline. It was a triumph for management, showing that Britain could produce world-class companies that could beat the best of the competition. Its success was the result of the process and strategy that management introduced. The process focused on creating a vision that would inspire the BA staff and gain their enthusiastic commitment.

It is certainly true that a great deal of effort and energy went into shaping BA's culture. At the heart of this was the 'Putting People First' training programme launched by Colin Marshall, the company's new chief executive, in December 1983. Originally intended for staff who had direct contact with customers it was, in fact, attended by all 40,000 employees by 1986 and it aimed to revolutionise their attitudes. In a direct challenge to the hierarchical and militaristic culture which existed in BA at the time, staff were instructed not to attend in uniform and, once on the course, put into cross-functional and cross-grade groups. The course itself was consciously designed to modify behaviour. Attendees were encouraged to take a more positive attitude to themselves, taught how to set personal goals and cope with stress and instructed in confidence building and 'getting what they wanted out of life'. Lapel badges inscribed with the motto "We're putting people first" provided a visible reminder of the course's message. 
The approach was self-conciously "indoctrinative". ${ }^{37}$ As Colin Marshall said "We ... have to 'design' our people and their service attitude just as we design an aircraft seat, an in-flight entertainment programme or an airport lounge to meet the needs and preferences of our customers" (cited in Barsoux and Manzoni ${ }^{38}$ emphasis added).

Colin Marshall's own personal commitment is one of the most written-about features of the PPF programme. He attended 95 per cent of all the PPF courses that ran, setting out his vision for BA and participating in question and answer sessions with staff $^{39}$ though this figure is reported as 40 per cent in Barsoux and Manzoni. ${ }^{40}$ This involvement extended beyond the PPF programme. Each time he flew the chief executive would introduce himself to front line staff and passengers and discuss their experience of BA. Once, when a queue formed at the launch of a new service he helped to deliver breakfasts to customers. ${ }^{41}$ In his presence all of the symbols of the 'new culture' were expected to be in place - even down to the PPF lapel badges. Staff not wearing one of these had replacements pinned in place and Colin Marshall wore his own PPF badge for two years. ${ }^{42}$

But the most impressive aspect of BA's cultural change is not so much the sophistication of the PPF programme itself, nor the commitment of executive time, but the extent to which other employment policies and practices were changed to fit the 'new' culture and the continued emphasis on these practices and programmes throughout the 1980s and 1990s. Three-quarters of the one hundred Customer First teams, formed to propagate the message of PPF, survived into the 1990s. Not only were team briefings and team working introduced but these were developed and 
refined with TQM, autonomous team working and multi-skilling introduced in many areas. Direct contact with all staff was considered so important that 'down route' briefings were developed to ensure that mobile and isolated staff were not neglected and in March 1996 BA became the first company to make daily TV broadcasts to its staff. $^{43}$

The way cabin crew were rostered was also changed. 'Families' of staff were created to work the same shift patterns. These were intended to provide mutual support, make cabin crew feel happier about their work environments and, as a result, facilitate the production of emotional labour. ${ }^{44}$ A new role of 'Passenger Group Co-ordinator' was introduced and staff appointed based entirely on personal qualities. The importance of emotional processes was also reflected in the new appraisal and reward systems such that work was judged on the way in which it was performed as well as against harder targets. ${ }^{45,46}$ Managerial bonuses could be as much as 20 per cent of salary and were calculated on a straight 50:50 split between exhibiting desired behaviours and achieving quantitative goals. Awards for Excellence and an Employee Brainwaves programme encouraged staff input. The Personnel Department was renamed 'Human Resources' with many decisions devolved to line managers and, in the first few years of the programme at least, a commitment was made to job security.

Closely following these developments, a Managing People First programme targeted managerial employees and aimed to bring their behaviours into line with a list developed by two consultancy firms (see table 2). As on PPF, the emphasis on this five-day course was on quasi-group therapy and experiential exercises. Outward bound courses were also intended to support the re-shaping of personality and the 
small groups formed on these residential programmes were expected to act as mutual support vehicles once back in the workplace.

\section{TABLE 2 ABOUT HERE}

Other courses were developed to maintain the momentum created by Putting People First and Managing People First. These included Winning for Customers, A Day in the Life, To Be the Best, Leading in a Service Business and Leadership 2000 and, while each was different, they all shared a focus on shaping staff emotions. The most dramatic form of this was probably the 'love bath' exercise in one of the early courses in which delegates took it in turns to sit in the centre of a circle while their colleagues complimented them ${ }^{47}$ for an account of participants' reactions to this process). Nearly twenty years after the launch of PPF, BA managers attending a training course were still being told about understanding themselves and taking responsibility: "understanding self is our starting point .... That means that to make a change within the airline we need to start with you - what can you do differently. In 1995, Bob Ayling, newly taken over from Colin Marshall as chief executive, continued this active management of company culture and said of his staff: "I want them to feel inspired, I want them to feel optimistic, I want them to feel that this is a good place to be". ${ }^{48}$

Such substantive change certainly seems to justify the plaudits heaped on it. But, as an account, it suffers from a number of flaws. Most significantly, as Anthony ${ }^{49}$ notes, together with other presentations of culture change it neglects structure. Yet the existence of cultural factors do not negate more material ones and there were certainly 
structural reasons for BA's success. Colin Marshall's emphasis on putting people first and caring for one another had been preceded by a rule of fear. BA's first response to its problems had been a massive series of redundancies, the largest in British history at the time, with staff numbers reduced by 40 per cent between 1981 and 1983 (albeit with generous severance). Senior staff were not exempt from this process, with 161 being 'removed' overnight on one memorable occasion in $1983 .{ }^{50}$

More fundamentally, the company was well provided with slots in Britain's prestigious Heathrow airport and faced little competition on many of the routes that it served. European markets were still tightly regulated and market share often depended on negotiation skills rather than competitive success. In 1987 just before privatisation, BA controlled some 60 per cent of the UK domestic market and only experienced competition on 9 per cent of routes into and out of the UK. ${ }^{51}$ Post privatisation its position was actually strengthened when it gained a 75 per cent share of domestic routes. ${ }^{52}$ Such was BA's dominance during this period that it could almost charge what it liked. Moreover, BA built up a series of alliances and mergers to consolidate this position.

While staff numbers were being drastically cut the infrastructure was dramatically improved. The fact that new uniforms were provided is well covered in the human resource and marketing literature. Less commonly noted is that BA invested in control systems, terminal facilities and aircraft. Between 1980 and 1985 BA replaced over half their fleet. ${ }^{53}$ Computer reservations were introduced, a series of hub and spoke routes through first Heathrow and then Gatwick networked flights, and selectively focused competitive pricing served to limit what little competition the 
airline faced. ${ }^{54}$ Nor was this the only strategy deployed against competitors. In 1993 BA used shared booking information to persuade Virgin customers to transfer to BA, informing them (incorrectly) that Virgin flights were no longer available. The subsequent court case fined BA $£ 610,000$ damages and $£ 3$ million costs. It raised questions about the extent of knowledge and invovlement of Lord King, the chairman, Sir Colin Marshall, the chief executive and Bob Ayling, the head of marketing as well as criticising the impact of the BA culture itself .

Not only can much of the BA turnaround be attributed to structural factors, but also the extent of the company's cultural transformation itself is open to question. There is little doubt that, in theory, cultural change interventions are both manipulative and totalitarian $^{55}$ seeking as they do influence and control over the thoughts, values, attitudes and norms of others. Yet such hegemony is easier to describe than it is to secure. Employees are not cultural dupes. Co-operation may reflect ambition or pride in work as much as (or instead of) a belief in the organisation itself. ${ }^{56,57,58}$ And Höpfl's (1993) account of British Airways managers in the 'new' culture reveals hostility and uncertainty as well as enthusiasm. Further, despite the claims of the prescriptive literature, the existence of 'culture management' does not ensure either that employees trust management, or that management trusts employees. So, in BA, 'new' management practices varied in the extent that they were introduced in departments and conflict between employees and management did not cease. Even at the point at which the company's unified culture was being heralded as a success at least one bargaining group a year ended up in dispute with it. ${ }^{59}$ 
Nor was the much vaunted job security quite as robust as it seemed. Alliances, mergers and franchising agreements with other airlines already supported what was, in effect a 'tiered' system of terms and conditions with employees based at Heathrow privileged over those in the regional airports. This emphasis on part-time, seasonal and sub-contracted work was extended to most aspects of BA's operations. Its engine overhaul plant was sold off to GEC, data processing work was moved to Bombay, and job security for existing staff questioned.$^{60,61,62}$ And all this at a time when BA was making record profits.

So, to re-cast our fairy-tale in rather more prosaic terms, BA, while clearly putting a great deal of effort into encouraging certain behaviours from (or 'designing') staff did not base its employment policies and practices around the new culture in the way that many accounts suggest. Their array of 'soft' human resource management techniques was certainly impressive but not everyone benefitted from them and those employed in partner, assoicate, merged or taken-over firms often experienced very different terms and conditions to the 'core' BA staff.

Nor is it fair to conclude, as many accounts do, with optimism about staff reactions to 'culture change'. There was enthusiasm and acceptance certainly, but there was also doubt, concern, opposition and open cynicism. Such individual reactions were mirrored by the collective representations and the persistence of disputes even at the height of the cultural success. As Colling ${ }^{63}$ argues "The relatively high incidence of conflict throughout the period fuels doubts about a transformation in the culture of the company towards the mutual commitment model". 
The 1997 Dispute: Change or Continuity?

By the end of the 1990s many of the structural factors that had provided the basis for the company's success were under threat. The emergence of low cost carriers such as Easyjet and Ryanair were undercutting BA's prices and, elsewhere, alliances between rivals Lufthansa and United Airlines ensured that cross national traffic would be less likely to transfer to BA. The company's hold on Heathrow was also loosening under double pressure from Europe and the USA. In response, Ayling claimed BA needed a second revolution. BA sought its own alliance with a different US carrier, American Airlines which came under the (unhurried) scrutiny of regulators in both Brussels and the USA, as well as proposing $£ 1$ billion of cost savings from within the organisation, with the aim of doubling profits by the year 2000. Much of this was to come from staff savings including 5,000 voluntary redundancies with staff to be replaced by newly hired employees on lower pay. ${ }^{64}$ In addition, BA established links with a charter airline called Flying Colours intending to continue its policy of outsourcing to other operators.

This policy of reducing labour costs was also extended to 'core' BA staff. In early 1997, BA attempted to change the structure of payments to cabin crew. It was proposed that the existing employees would be 'bought out' of their series of allowances (petrol, overnight stay etc) by receiving a higher basic wage. BA offered a three year guarantee that no crew member would earn less under the new system but nothing beyond that and it was clear to cabin crew staff that the measure was launched with the explicit aim of saving money. When these negotiations failed, one union, the TGWU, threatened strike action (Cabin Crew 89, a small breakaway union, 
had already accepted management's offer). Despite fourteen years of 'indoctrination' into caring for one another and putting people first, the tactics deployed by BA's management were described by two such different sources as the TUC and The Economist as bullying. ${ }^{65,66}$ Members of the cabin crew were warned not to strike and BA managers were instructed to tell discontented staff that anyone taking industrial action would be summarily sacked, then sued for damages. Any who simply stayed away would face disciplinary action, be denied promotion, and lose both pension rights and staff discounts on flights for three years. BA were also reported to be filming pickets.

The subsequent strike ballot had an 80 per cent turnout with 73 per cent of employees voting in favour of strike action. The TGWU called a series of 72-hour strikes with the first action scheduled for 9th July 1997. In response, temporary staff and an alternative workforce of 'volunteer managers' were given a (probably inadequate) training to perform the key tasks of the ground handling staff and BA threatened to take legal action over claimed discrepancies in the ballot. On the eve of the first day of action airline cabin crew were telephoned at home and warned that 'they had a duty to co-operate with their employer'.

These managerial actions certainly influenced the impact of the strike. On the first scheduled day of action less than three hundred workers declared themselves officially on strike but more than 2,000 called in sick. The company's threats and 'replacement workers' notwithstanding more than 70 per cent of flights from Heathrow were cancelled. It seemed that BA's macho approach had ensured only that collective action took the form of collective illness. 
Ironically this 'mass sickie' served to make things worse for BA. Not only did the prestrike ballots (conducted to comply with legislation designed to discourage union activities) compound the effects of the strike by providing customers with advance notice of it; but also those employees who had called in sick tended to stay away longer than the official 72-hour strike. BA insisted that sick employees provide a doctor's note within 48 hours instead of the normal seven days but many employees still stayed off for the full two weeks that their sick notes allowed and, throughout this period, services were cancelled and passengers turned away. The strike was costly. Airline seats are a particularly perishable form of consumer good and aircraft scheduling is easily disrupted. When Bill Morris, the General Secretary of the TGWU announced that he had written to Bob Ayling, suggesting that they resume negotiations, Ayling agreed before even receiving the letter.

The TGWU promised to save $£ 42$ million over three years. Catering was sold off but existing staff kept earnings and BA staff discounts, while sanctions against strikers were withdrawn and the TGWU increased its membership by 50 per cent to over 10,000. BA's management fared less well, despite Bob Ayling's claim that this agreement marked a 'new beginning and spirit of a co-operation'. The gulf between the managerial rhetoric on culture and official actions during the strike had a predictable effect on employee morale. One undercover employee publication, aptly named Chaos advised on ways of maximising payments by delaying aircraft. These included throwing duvet feathers into the engine, superglueing down the toilet seat and poisoning the pilot: "a particularly obnoxious captain can be made to suffer all the 
symptoms of violent food poisoning by emptying eye drops from the aircraft medical kit into his salad or drink".

Moreover, the agreement itself fostered further dissent. 4,000 staff left by the end of 1997 but 4,500 more were recruited including 2,000 in 1998. By the terms of the agreement, these new staff were employed on different contracts to existing employees. As a result, cabin crew working the same shifts on the same aircraft were (increasingly) on different payscales. The impact of this on both labour relations and BA's much prized teamworking was problematic and problems were fuelled by suggestions that staff on new contracts were favoured by BA in promotion to purser (first line manager).

Bob Ayling attempted to salvage the situation by placing more emphasis on managing the company's culture. Following Colin Marshall he addressed staff training sessions and held question and answer forums with groups of employees. This time there were few positive reactions. The strike cost BA £125 million; morale never entirely recovered and profits suffered. Between 1998 and 1999 they fell by 61 per cent and in 2000 British Airways announced losses of $£ 244$ million on its main business. While gains from disposals succeeded in keeping the company out of the red this was its worst performance (and first loss) since privatisation. The new logo Bob Ayling had launched (at great expense) during the 1997 dispute was unpopular and had to be withdrawn. These failures so coloured the public perception of the chief executive that even his attempts to refocus BA onto profitable routes and introduce a new seat for business class long haul passengers were not entirely welcomed. On March $10^{\text {th }}$ 2000, Bob Ayling resigned as chief executive. 
Conclusions and Discussion

Re-presenting our fairy story in case study format shows the company's turnaround in a different light with international agreements, competition with other airlines, the state of the fleet and the network of links between flights making a contribution to improved performance that was as least as significant as the cultural change programme itself. It is difficult to believe that, without these structural interventions BA's profits would have risen in the way that they did. ${ }^{67}$ Equally, the structural improvements may have served to enhance the cultural messages just as Bob Ayling's "Chicago-style union busting macho management" (George Galloway) ${ }^{68}$ made his seem hypocritical. As Grugulis et $\mathrm{al}^{69}$ argue in their study of a consultancy firm, it is naïve to assume that practices which are effective when companies are successful will be equally welcome at other times. Employees do not 'react' to the management of culture in isolation, nor does a 'positive' cultural rhetoric negate problematic experiences of job design, dis-empowerment, payment systems or control mechanisms. Rather, responses will be influenced by a person's experience of work as a whole and employees are more than capable of noting discrepancies between managerial promises and organisational practice.

This is not to suggest that BA's cultural change was unimportant. Indeed, the move to 'design' employees, to shape the way they think and feel about their work rather than simply control what they produce is a new development. A growing service sector and an increasing focus on customer service in all industries has resulted in an emphasis on the service process (of which the employee is an integral part) rather than 
a manufactured product. Clearly such a development has and will lead to fundamental changes in the way work is shaped. But these changes are not attempts to make work "more fun". They represent a new means of management control $^{70}$ targeted on staff emotions. So personalities and individuals are valued only within pre-determined limits. ${ }^{71}$

Here, BA's programme of culture change was not an expression of mutual trust and reciprocal emotional obligations between the company's employees and its management. Rather, it was an alternative control mechanism and should be understood as such. The way that this control mechanism is implemented and the consequences that it has differ from other forms of personal, technical or bureaucratic control; but management by culture is not automatically either better or worse than other forms of regulation and may inspire varied responses. Employees may feel genuine pride in a culture management programme $e^{72,73}$ or may desire to use it towards their own ends. ${ }^{74}$ Equally they may feel embarrassment or cynicism set up active opposition or use the culture change as a vehicle for misbehaviour and structural factors may influence and inform these responses. The 'successes' and 'failures' of these interventions are not magical, nor do they occur in environments that have no legacy of employee relations. But this point is clearest when case studies are extended beyond anecdote and prescription, a development which might encourage better practitioners as well as better academics.

The end of the fairy tale: lessons for managers

Presenting an account of cultural change in realistic terms does not necessarily mean that culture management should not be attempted, rather, it is a condemnation of 
rhetorical flourishes unaccompanied by substantive change and of seeking to use people as a means to an end. The notion of mutual trust between employer and employees underlies both the ideal type of culture management and most forms of high commitment human resource management. In practice this process is rarely reciprocal and employees may find themselves required to change their practices and beliefs to order while senior management observe and monitor. This is not a recipe for increasing trust, no matter how well it is packaged.

Accordingly, the recommendations for manager begin with:

- Practice what you preach. The success of Novotel's culture change ${ }^{75}$ and Colin Marshall's popularity in British Airways may have been because the management of culture did not stop at the shopfloor. If the corporate message is 'putting people first' (and this is a valuable message for any society) then the full implications of this should be appreciated and enacted.

- However evangelically presented, a culture is not a religion and insisting on one true dogma will lead only to heresy and schism. Diversity and dissent are signs of a healthy society.

- A culture is both influenced by, and influences, structures. Internally this means that employment policies and practices should be coherent and support central message conveyed by the culture. Inconsistencies here will provoke (justified) accusations of hypocrisy and (at best) the new culture will become the butt of employee humour. Externally, the competitive environment will affect the way that 'cultural messages' are interpreted and enacted. 
There are always structural tensions in the employment relationship. Employees' interest naturally differ from those of employers and no culture management programme can entirely eliminate these or correct the asymetry of power that exists. However, well designed employment practices, introduced in an environment of trust, can materially improve employment relations, and that must be a welcome development. 


\section{BIBLIOGRAPHY}

Irena Grugulis is a lecturer in Employment Studies at Manchester School of Management, UMIST and an associate fellow of SKOPE, University of Warwick/University of Oxford. She has researched into and published on NVQs, management training, the nature of managerial work and managing culture as well as a recent book on Customer Service published by Palgrave. She has been funded by both the ESRC and the ERDF and sits in the ESRC's Management, Linguistics, Philosophy and Education College. She was a founding organiser of the International Critical Management Studies Conference.

Adrian Wilkinson is Professor of Human Resource Management and Research Director at Loughborough University Business School. He has written extensively on many aspects of Human Resource Management and Industrial Relations. Recent research has encompassed change initiatives such as TQM, the changing nature of Employee Participation, and Employment Relations in Financial Services. In the last few years he has attracted grants from the Economic and Social Research Council, the Engineering and Physical Sciences Research Council, the European Regional Development Fund, the NHS Executive, the Chartered Institute of Personnel and Development, and the European Foundation for Quality Management. He has written five books, three monographs, fifty articles in refereed journals as well as more than twenty book chapters and numerous other articles. He has published in Organization Studies, Human Relations, British Journal of Industrial Relations, Academy of Management Review, International Journal of Human Resource 
Management, Human Resource Management Journal and Work, Employment \& Society. His work has been translated into several languages including French, German, Dutch and Chinese. He is on the editorial board of several refereed journals and is also a Consulting Editor for the International Journal of Management Reviews. 


\section{REFERENCES}

1. Peters, T., and Waterman, R., In Search of Excellence, London: Harper and Row, (1982).

2. Georgiades, N., and Macdonell, R., , Leadership for Competitive Advantage, London: John Wiley, (1998).

3. Blyton, $\mathrm{P}$ and Turnbull, P., The Dynamics of Employee Relations ( $2^{\text {nd }}$ Edition) Macmillan, (1998).

4. Legge, K. Human Resource Management: Rhetorics and Realities London: MacMillan, (1995).

5. Colling, T., Experiencing turbulence: competition, strategic choice and the management of human resources in British Airways, Human Resource Management Journal I 5(5), 18-32 (1995).

6. See ref. 1

7. Pfeffer, J. The Human Equation, Boston: Harvard Business School Press, (1998).

8. Marchington, M. 'Fairy tales and magic wands: new employment practices in perspective' Employee Relations 17(1), 51 - 65 (1995).

9. See ref. 2

10. See ref. 3

11. See ref. 5

12. Ogbonna, E., 'Managing organisational culture: fantasy or reality?' Human Resource Management Journal 3(2), 42-54 (1992/1993).

13. See ref. 1, pxxv.

14. Kunda, G. Engineering Culture: control and commitment in a High-Tech corporation Philadelphia: Temple University Press, (1992).

15. Grugulis, I., Dundon, T. and Wilkinson, A. 'Cultural control and the "culture manager": employment practices in a consultancy' Work, Employment and Society 14(1), 97 - 116 (2000).

16. Collinson, D. Managing the Shopfloor, Berlin: de Gruyter, (1992).

17. Hamper, B. Rivethead: Tales from the Assembly Line London: Fourth Estate, (1992). 
18. Keenoy, T. and Anthony, P. 'HRM: metaphor, meaning and morality' in Blyton, P. and Turnbull, P. (eds.) Reassessing Human Resource Management London:Sage, (1992).

19. Ogbonna, E. and Wilkinson, B. 'Corporate strategy and corporate culture: the management of change in the UK supermarket industry' Personnel Review 17(6), $10-14,(1988)$.

20. Ogbonna, E. and Wilkinson, B. (1990) 'Corporate strategy and corporate culture: the view from the check-out' Personnel Review 19(4), 9-15 (1990).

21. See ref. 14

22. Casey, C. Work, Self and Society: After Industrialism, Routledge: London and New York, (1995).

23. See ref. 15

24. Watson, T.J. In Search of Management London: Routledge, (1994).

25. Storey, J. Developments in the Management of Human Resources, Oxford: Blackwell, (1992).

26. Reed, M., The Sociology of Organization, London: Harvester Wheatsheaf, (1992), p205.

27. See ref. 15

28. See ref. 14

29. Hochschild, A.R. The Managed Heart: Commercialization of Human Feeling Berkley:University of California Press, (1983).

30. Ackroyd, S. and Crowdy, P.A. 'Can culture be managed? Working with 'raw' material: the case of the English slaughterman' Personnel Review 19(5), 3-13, (1990).

31. Corke, A. (1986) British Airways: The Path to Profitability, London: Frances Pinter.

32. Warhurst, R. 'Converging on HRM? Change and Continuity in European Airlines' Industrial Relations' European Journal of Industrial Relations 1(2), 259 - 274, (1995).

33. See ref. 3

34. Financial Times $9^{\text {th }}$ July, (1997).

35. Financial Times $18^{\text {th }}$ March, (2000).

36. Doyle, P., From the Top, The Guardian, $4^{\text {th }}$ December (1999).

37. Bate, P., 'Strategies for cultural change, London: Butterworth Heinemann, (1994). 
38. Barsoux, J-L and Manzoni, J-F., Becoming the World's Favourite Airline: British Airways 1980 - 1993, Bedford: European Case Clearing House, (1997a).

39. See ref. 2

40. See ref. 38

41. Höpfl, H., 'Culture and commitment: British Airways' in Gowler, D., Legge, K. and C. Clegg. Case studies in Organizational Behaviour and Human Resource Management, London: PCP, (1993).

42. See ref. 2

43. See ref. 5

44. See ref. 38

45. See ref. 2

46. See ref. 41

47. See ref. 41

48. Dangerous Company, BBC2, April, (2000).

49. Anthony, P.D., Managing Culture Buckingham: Open University Press, (1994).

50. See ref. 38

51. Monopolies and Mergers Commission, British Airways plc and British Caledonian Group plc: A Report on the Proposed Merger 247 London:HMSO, (1987).

52. See ref. 5

53. See ref. 5

54. Blyton, P. and Turnbull, P., 'Confusing Convergence: Industrial Relations in the European Airline Industry - A Comment on Warhurst' European Journal of Industrial Relations 2(1), 7 - 20, (1996).

55. Willmott, H. 'Strength is ignorance; slavery is freedom: managing culture in modern organisations' Journal of Management Studies 30(4), 515-552, (1993).

56. Korczynski, M. 'The contradictions of service work: call centre as customeroriented bureaucracy' in Sturdy, A., Grugulis, I. and Willmott, H. (eds.) Customer Service: Empowerment and Entrapment Basingstoke: Palgrave, (2001).

57. Hill, S. 'From Quality Circles to Total Quality Management' in Wilkinson, A. and Willmott, H. (eds.) Making Quality Critical London: Routledge, (1995).

58. See ref. 41 
59. See ref. 5

60. See ref. 32

61. See ref. 55

62. See ref. 5

63. See ref. 5, p25.

64. See ref. 3

65. Taylor, R., Annual Review Article, British Journal of Industrial Relations, 36(2), 293-311, (1998).

66.The Economist, $27^{\text {th }}$ July (1997).

67. See ref. 1

68. George Galloway MP Newsnight, 10 ${ }^{\text {th }}$ July, (1997).

69. See ref. 15

70. See ref. 26

71. See ref. 37

72. See ref. 14

73. See ref. 15

74. See ref. 25

75. Calori et al (2000) 


\section{TABLES}

Table 1. The Gap, Words to Live By

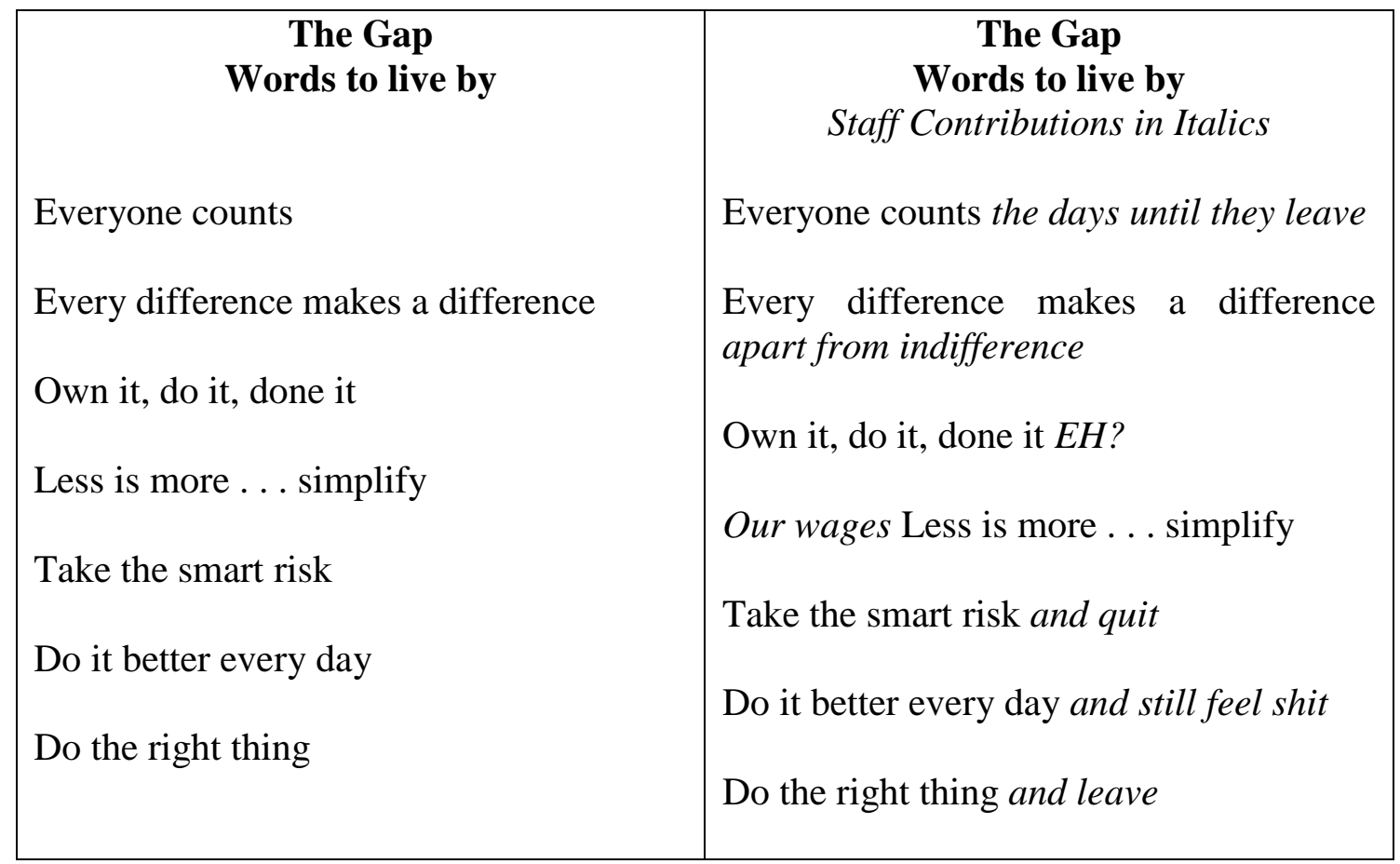

Table 2 The four factor menu of practices used in British Airways in 1984 - 1985 (Source:

Georgiades and Macdonnell, 1998 p 174).

\section{THE MENU OF PRACTICES}

FACTOR I

CLARITY AND HELPFULNESS

Establishing clear, specific objectives for subordinates

Helping subordinates to understand how their jobs contribute to the overall performance of the organisation

Clearly defining standards of excellence required for job performance

Providing help, training and guidance for subordinates

Giving subordinates a clear-cut decision when they need one
FACTOR II PROMOTING ACHIEVEMENT

Emphasising and demonstrating commitment to achieving goals

Giving subordinates feedback on how they are doing

Communicating your views to others honestly and directly about their performance

Recognising people more often than criticising them

Recognising subordinates for innovation and calculated risk taking 


\section{FACTOR III \\ FACTOR IV \\ INFLUENCING THROUGH \\ CARE AND TRUST \\ PERSONAL EXCELLENCE AND TEAMWORKING}

Knowing and being able to explain to Behaving in a way that leads others to others the mission of the organisation and trust you

how it relates to their jobs

Communicating high personal standards Building warm, friendly relationships informally through appearance and dedication

Noticing and showing appreciation for Paying close attention to what people are extra effort saying

Sharing power in the interest of achieving Responding non-defensively when others overall organisation objectives disagree with your views

Willing to make tough decisions in Making sure that there is a frank and implementing corporate strategy open exchange at work group meetings 